\title{
Insertional Mutagenesis and Cloning of the Genes Required for Biosynthesis of the Host-Specific AK-Toxin in the Japanese Pear Pathotype of Alternaria alternata
}

\author{
Aiko Tanaka, ${ }^{1}$ Hiroshi Shiotani, ${ }^{1}$ Mikihiro Yamamoto, ${ }^{2}$ and Takashi Tsuge ${ }^{1}$ \\ ${ }^{1}$ Graduate School of Bioagricultural Sciences, Nagoya University, Chikusa, Nagoya 464-8601, Japan; \\ ${ }^{2}$ College of Agriculture, Okayama University, Okayama 700-8530, Japan \\ Accepted 30 April 1999.
}

\begin{abstract}
The Japanese pear pathotype of Alternaria alternata causes black spot of Japanese pear by producing a hostspecific toxin known as AK-toxin. Restriction enzymemediated integration (REMI) mutagenesis was used to tag genes required for toxin biosynthesis. Protoplasts of a wild-type strain were treated with a linearized plasmid along with the restriction enzyme used to linearize the plasmid. Of 984 REMI transformants recovered, three produced no detectable AK-toxin and lost pathogenicity on pear leaves. Genomic DNA flanking the integrated plasmid was recovered from one of the mutants. With the recovered DNA used as a probe, a cosmid clone of the wild-type strain was isolated. Structural and functional analyses of an $8.0-\mathrm{kb}$ region corresponding to the tagged site indicated the presence of two genes. One, designated $A K T 1$, encodes a member of the class of carboxylactivating enzymes. The other, $A K T 2$, encodes a protein of unknown function. The essential roles of these two genes in both AK-toxin production and pathogenicity were confirmed by transformation-mediated gene disruption experiments. DNA gel blot analysis detected $A K T 1$ and $A K T 2$ homologues not only in the Japanese pear pathotype strains but also in strains from the tangerine and strawberry pathotypes. The host-specific toxins of these two pathotypes are similar in structure to AK-toxin. Homologues were not detected in other pathotypes or in nonpathogenic strains of $A$. alternata, suggesting acquisition of $A K T 1$ and $A K T 2$ by horizontal transfer.
\end{abstract}

Corresponding author: Takashi Tsuge; Address: Graduate School of Bioagricultural Sciences, Nagoya University, Chikusa, Nagoya 464-8601, Japan; Telephone: 81-52-789-4030; Fax: 81-52-789-4012;

E-mail: ttsuge@agr.nagoya-u.ac.jp

Current address of Hiroshi Shiotani: Department of Citriculture, National Institute of Fruit Tree Science, 870 Otsu, Kuchinotsu-Cho, Nagasaki 859-2501, Japan.

Nucleotide and/or amino acid sequence data for $A K T 1$ and $A K T 2$ are to be found in the DDBJ, GenBank, and EMBL data bases as accession numbers $\mathrm{AB} 015351$ and $\mathrm{AB} 015352$, respectively.

This paper is dedicated to the late Syoyo Nishimura, who provided us the opportunity to carry out this study and to learn his eminent way of thinking about host-specific toxins.
There are seven known host-parasite combinations in which host-specific toxins produced by Alternaria alternata (Fr.:Fr.) Keissl. are responsible for disease (Nishimura and Kohmoto 1983; Kohmoto et al. 1995). Host-specific toxins are lowmolecular-weight metabolites of diverse structure (Nishimura and Kohmoto 1983; Kohmoto et al. 1995). The participation of host-specific toxins in establishment of plant disease is one of the most clearly understood mechanisms of host-selective pathogenesis (Yoder 1980; Nishimura and Kohmoto 1983; Scheffer and Livingston 1984; Walton 1996).

Previously, species names were adopted for Alternaria pathogens that produce particular host-specific toxins (Nishimura and Kohmoto 1983). However, measurements of conidial size of these pathogens fall statistically within the range described for A. alternata, a ubiquitous, usually saprophytic, fungus (Nishimura et al. 1978; Nishimura 1980). Each pathogen has a distinct host range due to the production of a particular host-specific toxin, and thus it is possible to distinguish one type of pathogen from another (Nishimura et al. 1978; Nishimura 1980). Based on these features, Nishimura et al. (1978; Nishimura 1980) proposed that the Alternaria pathogens be defined as distinct pathotypes of A. alternata. Support for this classification was provided by molecular analyses of nuclear ribosomal DNA and mitochondrial DNA (Kusaba and Tsuge 1994, 1995, 1997). Thus, these pathogens provide an interesting example of intraspecific variation and evolution of pathogenicity in plant-pathogenic fungi.

To understand the molecular basis of pathogenic specialization, our efforts have focused on cloning the genes required for host-specific toxin biosynthesis. We have concentrated on the Japanese pear pathotype that produces a host-specific toxin known as AK-toxin (Fig. 1) and causes black spot of certain cultivars of Japanese pear, including the commercially important cultivar Nijisseiki (Tanaka 1933; Nakashima et al. 1985; Otani et al. 1985). Black spot disease of Japanese pear first became prominent in the early 1900s, shortly after cultivation of Nijisseiki pear was initiated, and has been the most critical problem in pear cultivation since (Tanaka 1933; Nishimura and Kohmoto 1983). Host-specific toxins from $A$. alternata pathogens are diverse in structure (Nishimura and Kohmoto 1983; Kohmoto et al. 1995). However, AK-toxin of the Japanese pear pathotype, AF-toxin of the strawberry pathotype, and ACT-toxin of the tangerine pathotype have a common moiety, 9,10-epoxy-8-hydroxy-9-methyl-decatrienoic 
acid, in their structures (Fig. 1) (Nakashima et al. 1985; Nakatsuka et al. 1986; Kohmoto et al. 1993). This common moiety has been identified as a precursor of the toxins (Feng et al. 1990; Nakatsuka et al. 1990; Kohmoto et al. 1993). Thus, we hypothesize that these three pathotypes share genes encoding the enzymes for biosynthesis of 9,10-epoxy-8hydroxy-9-methyl-decatrienoic acid.

Although the chemical structures of the Alternaria hostspecific toxins have been elucidated, knowledge of toxin biosynthesis is limited (Feng et al. 1990; Nakatsuka et al. 1990). Conventional genetic analysis is not possible with A. alternata, which lacks a known sexual cycle. Recently, the restriction enzyme-mediated integration (REMI) technique was developed for efficient transformation and tagging mutagenesis in fungi. This method was first described for Saccharomyces cerevisiae (Schiestl and Petes 1991) and then applied to Dictyostelium discoideum (Kuspa and Loomis 1992) and other fungi ( $\mathrm{Lu}$ et al. 1994; Bölker et al. 1995; Shi et al. 1995; Sweigard et al. 1998). In the maize pathogen Cochliobolus heterostrophus, the REMI technique was successfully used to tag and clone a gene, PKS1, that encodes a polyketide synthase required for biosynthesis of a host-specific toxin known as T-toxin (Lu et al. 1994; Yang et al. 1996). Enhanced transformation efficiencies and mutagenesis by REMI have been recently reported in the tomato pathotype of A. alternata (Akamatsu et al. 1997).

We report here REMI tagging, cloning, and characterization of genes required for AK-toxin biosynthesis of the Japanese pear pathotype. We identified two genes, AKT1 and $A K T 2$, essential for both toxin production and pathogenicity.

\section{RESULTS}

\section{REMI transformation.}

Plasmid pSH75, which carries the hygromycin B resistance gene $(h p h)$ as a selectable marker with no homology to $A$. alternata DNA (Tsuge et al. 1990; Kimura and Tsuge 1993), was used for transformation. When protoplasts (about $10^{7}$ ) of wild-type strain $15 \mathrm{~A}$ were treated with circular or linearized pSH75 DNA $(5 \mu \mathrm{g})$ in $200 \mu \mathrm{l}$ of transformation mixture, transformants arose at low frequency (usually less than 10 transformants). Addition of restriction enzyme markedly increased the transformation rate: the best results (103 to 156 transformants) were obtained when $50 \mathrm{U}$ of $\mathrm{BamHI}$ or $100 \mathrm{U}$ of HindIII was used.

\section{Isolation of Tox ${ }^{-}$mutants.}

A total of 984 REMI transformants were tested for pathogenicity to Nijisseiki pear leaves. Three transformants, designated ATA95-1, ATA95-2, and ATA95-3, resulting from HindIII-mediated integration appeared to completely lose pathogenicity (Fig. 2A). AK-toxin production was tested with a bioassay involving Nijisseiki leaves, which is the most sensitive method for detection of toxin (Hayashi et al. 1990). Culture filtrates, mycelial extracts, and spore germination fluids of the wild-type strain showed toxicity to Nijisseiki pear leaves, but those of the nonpathogenic mutants had no toxicity (Fig. 2B-D), indicating loss of AK-toxin production. AKtoxin has been characterized as two related molecular species, AK-toxins I and II (Fig. 1), with toxin I being the predominant species with respect both to yield and to biological activity
(Nakashima et al. 1985; Otani et al. 1985). Toxins I and II were quantified by reverse-phase high-performance liquid chromatography. Toxin I was detected in culture filtrates (94.2 $\left.\mathrm{ng} \cdot \mathrm{ml}^{-1}\right)$, mycelia $\left(400 \mathrm{ng} \cdot \mathrm{g}^{-1}\right)$, and spore germination fluid $\left(12.5 \mathrm{ng} \cdot \mathrm{ml}^{-1}\right)$ of the wild-type strain, but not in those of the mutants. Toxin II was not detectable in wild type and mutants. A precursor of AK-toxin, 9,10-epoxy-8-hydroxy-9-methyldecatrienoic acid (Feng et al. 1990; Nakatsuka et al. 1990), in culture filtrates was also quantified by high-performance liquid chromatography. 9,10-epoxy-8-hydroxy-9-methyl-decatrienoic acid was present in culture filtrate of the wild-type strain $\left(686 \mathrm{ng} \cdot \mathrm{ml}^{-1}\right)$ but not in those of three mutants, suggesting that these mutants lost the ability to produce this precursor. All mutants were prototrophic, and grew and sporulated as well as the wild-type strain (data not shown). There were no significant differences in spore germination, appressorium formation, or hyphal penetration on cellulose membranes between the wild type and each of these mutants (data not shown). These results suggest that all mutations that affect pathogenicity are attributable to loss of AK-toxin production.

\section{Characterization of the plasmid insertion sites in Tox mutants.}

To analyze plasmid integration events in three $\mathrm{Tox}^{-} \mathrm{mu}-$ tants, total DNA was digested to completion with restriction

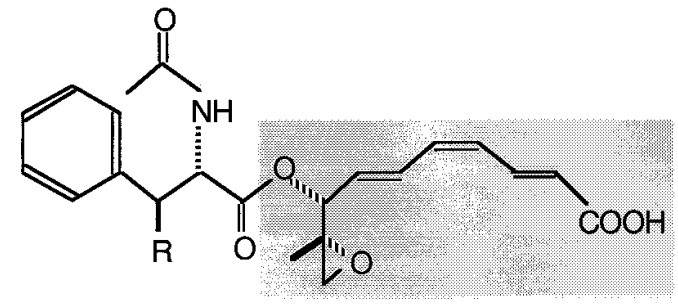

AK-toxin I: $\mathrm{R}=\mathrm{CH}_{3}$
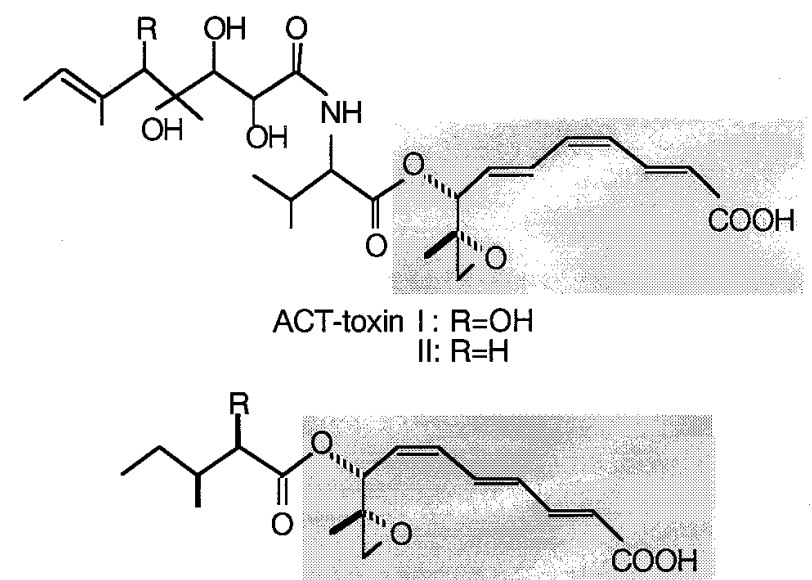

AF-toxin I : $\mathrm{R}=\mathrm{OCOCH}(\mathrm{OH}) \mathrm{C}\left(\mathrm{CH}_{3}\right)_{2} \mathrm{OH}$ II : $\mathrm{R}=\mathrm{OH}$ III: $\mathrm{R}=\mathrm{OCOCH}(\mathrm{OH}) \mathrm{CH}\left(\mathrm{CH}_{3}\right)_{2}$

Fig. 1. Structure of host-specific toxins produced by three pathotypes of Alternaria alternata. AK-toxins of the Japanese pear pathotype (Nakashima et al. 1985), ACT-toxins of the tangerine pathotype (Kohmoto et al. 1993), and AF-toxins of the strawberry pathotype (Nakatsuka et al. 1986) have a common moiety, 9,10-epoxy-8-hydroxy9-methyl-decatrienoic acid, indicated in shadowed boxes. 
enzymes, electrophoresed, blotted, and probed with ${ }^{32} \mathrm{P}-$ labeled pSH75. The pSH75 probe did not hybridize to total genomic DNA of the wild-type strain. The analysis showed that the plasmid integration events in these mutants were complex. ApaI, which has no site in $\mathrm{pSH} 75$, produced only high- molecular-weight hybridizing bands $(>23 \mathrm{~kb})$ in all mutants, suggesting multiple-copy integration of plasmids as tandem repeats (Fig. 3). HindIII, which was used in REMI transformation and has one site on $\mathrm{pSH} 75$, also produced only high-molecular-weight hybridizing bands $(>23 \mathrm{~kb})$, and no 5.5-kb band (the size of pSH75), demonstrating that the HindIII site on the plasmid had been lost, or that pSH75 did not insert at a HindIII site (Fig. 3). EcoRV, which has a single site in pSH75, was also used in the analysis. DNA of all the mutants shared a 5.5-kb EcoRV fragment, the size of pSH75, derived from tandem repeats of integrated pSH75 (Fig. 3). ATA95-3 had two faint additional bands, which probably correspond to the junctions between the recipient genomic DNA and integrated pSH75 (Fig. 3). ATA95-1 and ATA95-2 had several additional bands, which seem to have resulted from rearrangements of integrated plasmids (Fig. 3). These results demonstrate multiple-copy integration of plasmids in all mutants and rearrangements of integrated plasmids in ATA95-1 and ATA95-2.

\section{Isolation of the DNA at the tagged locus.}

Complex integration patterns of the transforming plasmid made it difficult to recover genomic DNA flanking the tag by plasmid rescue. Thus, genomic libraries of $\mathrm{Tox}^{-}$mutants were screened with ${ }^{32} \mathrm{P}$-labeled pSH75 and subsequently with ${ }^{32} \mathrm{P}$ labeled total DNA of the wild-type strain. Two positive clones, which hybridized to both probes, were isolated each from the library of ATA95-1 or ATA95-3. We first analyzed two clones of ATA95-3, because the plasmid integration pat- tern in this mutant was not as complex as in the other mutants (Fig. 3). Nucleotide sequencing of DNA flanking the plasmid insertion site in these clones detected the same sequences, which are highly homologous to long terminal repeat retrotransposons of Magnaporthe grisea (Dobinson et al. 1993; Farman et al. 1996). We did not think that the retrotransposonlike sequence has direct involvement in AK-toxin biosynthesis. Thus, we focused on the two clones of ATA95-1, named $\lambda$ ATA $1-1$ and $\lambda$ ATA $1-2$.

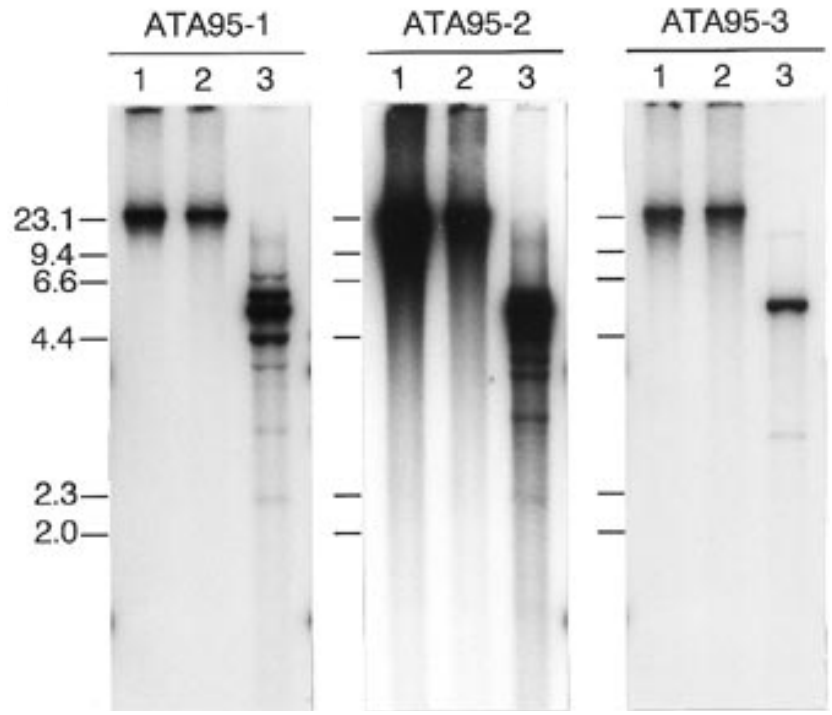

Fig. 3. DNA gel blot analysis of the Tox ${ }^{-}$mutants of Alternaria alternata. Total DNA was digested with (lane 1) ApaI, (lane 2) HindIII, or (lane 3) EcoRV and separated in an $0.8 \%$ agarose gel. Blots were probed with pSH75. Sizes (in kilobases) of marker DNA fragments (HindIIIdigested $\lambda$ DNA) are indicated on left.
A

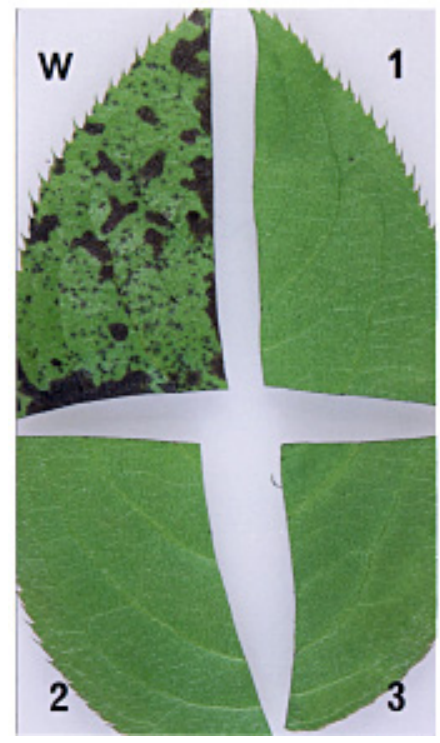

B

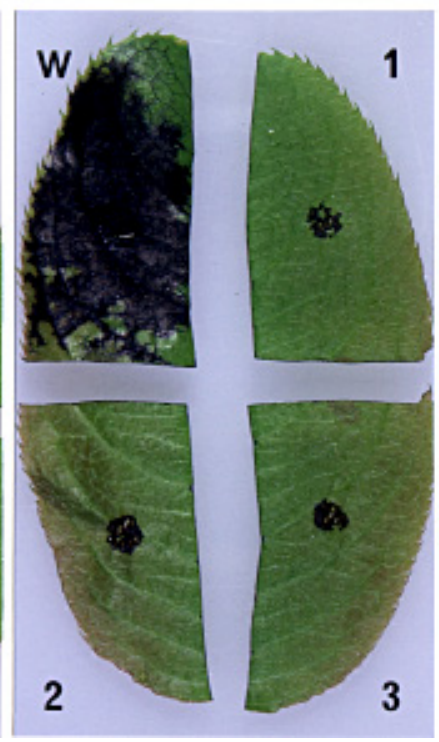

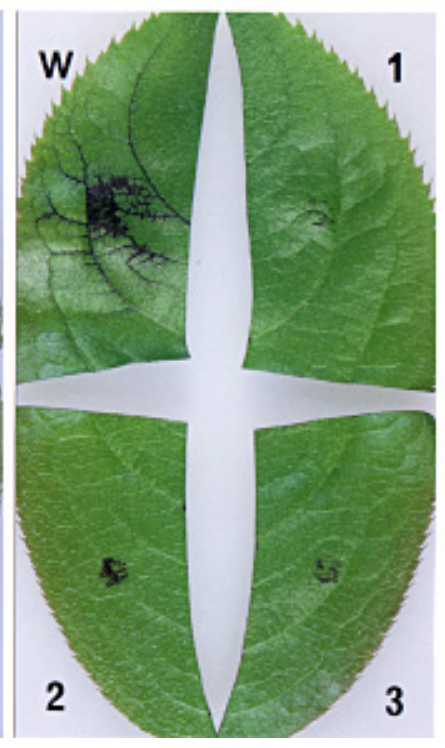

D
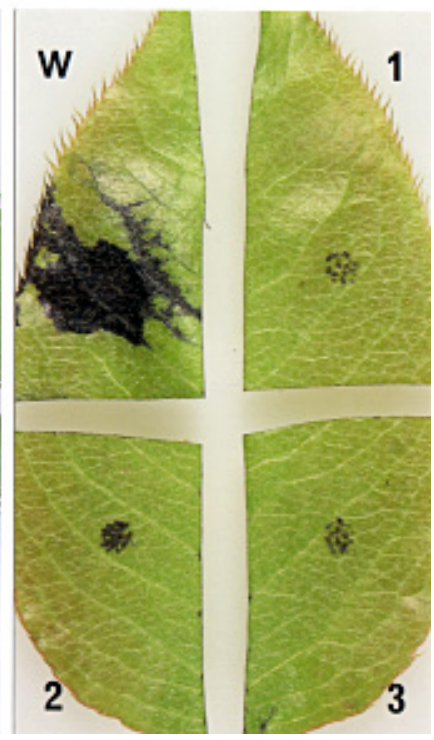

Fig. 2. Pathogenicity and AK-toxin production by Alternaria alternata wild-type strain 15A (W) and mutants ATA95-1 (1), ATA95-2 (2), and ATA95-3 (3). A, Detached leaves of susceptible pear cultivar Nijisseiki were spray inoculated with spore suspensions and incubated in a moist box at $25^{\circ} \mathrm{C}$ for 20 h. B-D, Detached leaves were wounded slightly: (B) culture filtrates, (C) mycelial extracts, or (D) spore-germination fluids were placed on the wounded portion and incubated in a moist box at $25^{\circ} \mathrm{C}$ for $20 \mathrm{~h}$. 
Restriction mapping of these clones with EcoRI and EcoRV showed that they contained the same side of the plasmid integration site (Fig. 4). $\lambda$ ATA1-1 confirmed that multiple copies of the vector were present (Fig. 4). The 6.2-kb EcoRI fragment, which consists of the Escherichia coli plasmid pSP72 and flanking fungal DNA, was rescued in E. coli as pATA1-1 (Fig. 4). Restriction mapping of pATA1-1 showed that there were no HindIII sites at the junction of genomic DNA and integrated plasmid as predicted (Fig. 4).

To confirm that the recovered DNA corresponds to the plasmid integration site in mutant ATA95-1, the SphI-XhoI fragment (Fr. S-X) in the pATA1-1 insert (Fig. 4) was used to probe a DNA gel blot. Total DNA of wild type and mutant was digested with EcoRV, which has no site in the probe fragment (Fig. 4). Unexpectedly, the probe hybridized to two bands of 2.8 and $3.2 \mathrm{~kb}$ in the wild-type strain; the $2.8-\mathrm{kb}$ band was more intense than the $3.2-\mathrm{kb}$ band, indicating that the wild-type strain has multiple copies of genomic DNA homologous to the probe (Fig. 5). The mutant had the intense $2.8-\mathrm{kb}$ band found in the wild type, but not the weak $3.2-\mathrm{kb}$ band, and carried a new band of $5.1 \mathrm{~kb}$ resulting from plasmid integration (Figs. 4 and 5). These results imply that the $3.2-\mathrm{kb}$ band represents a gene essential for toxin production, and that

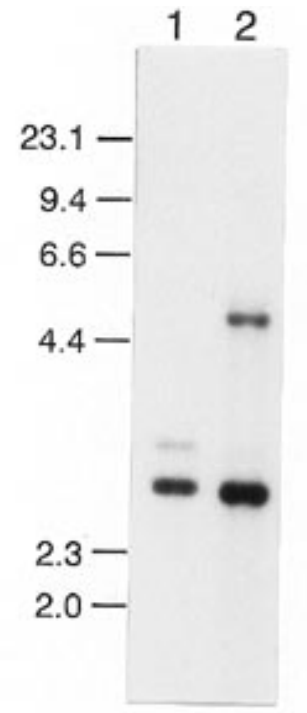

Fig. 5. DNA gel blot analysis of (lane 1) wild-type strain 15A and (lane 2) mutant ATA95-1. Total DNA was digested with EcoRV and separated in an $0.8 \%$ agarose gel. Blot was probed with the $S p h \mathrm{I}-X h o \mathrm{I}$ fragment (Fr. S-X) in the pATA1-1 insert (see Figure 4). Sizes (in kilobases) of marker DNA fragments (HindIII-digested $\lambda$ DNA) are indicated on left.

$\lambda$ ATA1-1

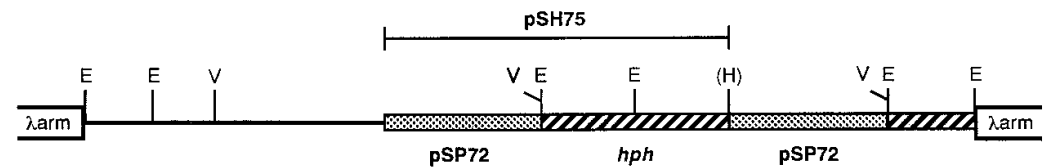

גATA1-2

PATA1-1

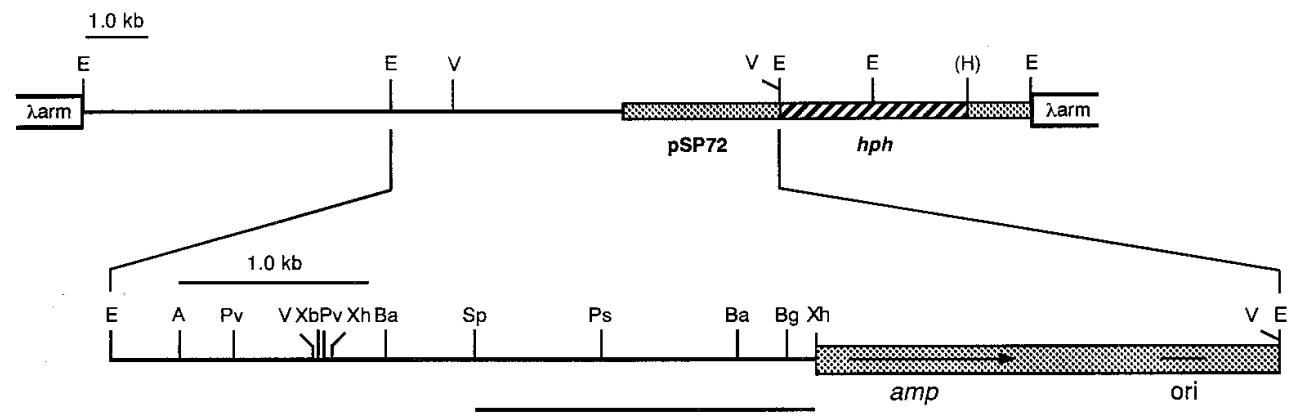

Fr. S-X

PCAKT-1

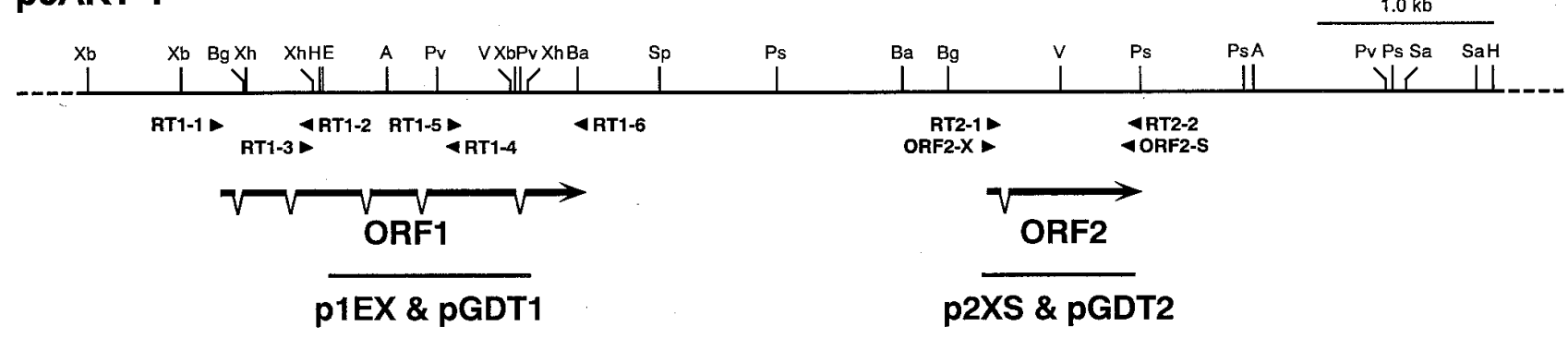

Fig. 4. Structure of the genomic locus tagged with pSH75 in Tox ${ }^{-}$mutant ATA95-1. $\lambda$ ATA1-1 and $\lambda$ ATA1-2 were isolated from a genomic phage library of ATA95-1. The 6.2-kb EcoRI fragment consisting of the Escherichia coli plasmid pSP72 and its flanking fungal DNA was recovered from $\lambda$ ATA1-1 by plasmid rescue as pATA1-1. The SphI-XhoI fragment (Fr. S-X) in pATA1-1 was used as a probe for hybridization experiments. pcAKT-1 was isolated from a genomic cosmid library of wild-type strain $15 \mathrm{~A}$ by screening with $\mathrm{Fr}$. S-X probe, and the 8.0-kb region was sequenced. Arrows indicate the protein coding regions, designated ORF1 and ORF2. Positions of introns are indicated by "V" shapes. Arrowheads above ORF1 and ORF2 denote orientation and location of oligonucleotide primers used in polymerase chain reaction (PCR) and reverse transcription-PCR experiments. p1EX and p2XS were made by cloning the indicated fragments in pBluescript $\mathrm{KS}^{+}$and pGEM-T Easy, respectively, and used as probes for hybridization experiments. Fragments were also cloned in pSH75 (Kimura and Tsuge 1993) to produce the targeted disruption vectors pGDT1 and pGDT2. Abbreviations: A, ApaI; Ba, BamHI; Bg, BglII; E, EcoRI; H, HindIII; Ps, PstI; Pv, PvuII; Sa, SalI; Sp, SphI; V, EcoRV; Xb, XbaI; Xh, XhoI. 
the intense band might carry multiple copies of homologues nonfunctional in toxin production.

A cosmid genomic library of the wild-type strain was screened with ${ }^{32}$ P-labeled Fr. S-X (Fig. 4). Positive clones were digested with EcoRV and hybridized with the same probe. A clone containing the 3.2-kb EcoRV fragment hybridizing to the probe was isolated and named pcAKT-1 (Fig. 4).

\section{Identification of two open reading frames in the tagged locus.}

The region within pcAKT-1 corresponding to the tagged site in mutant ATA95-1 was identified, and the nucleotide sequence of an 8.0-kb region determined. No HindIII (the enzyme used in the original REMI transformation) site was detected at the plasmid integration site in ATA95-1 (Fig. 4). Sequencing of the junction of plasmid and genomic DNA in pATA1-1 demonstrated that eight nucleotides at the end of the plasmid including the HindIII site had been deleted during the integration process. The DNA sequence of the $8.0-\mathrm{kb}$ genomic region was analyzed for putative protein coding regions. The analysis identified two open reading frames, designated ORF1 and ORF2 (Fig. 4).

ORF1 (1,734 bp) potentially encodes a 578 amino acid protein after splicing of five putative introns (Fig. 4). Introns were deduced on the basis of presence of consensus sequences for $5^{\prime}$ splice sites $[\mathrm{GT}(\mathrm{A} / \mathrm{G} / \mathrm{T})(\mathrm{A} / \mathrm{C} / \mathrm{T}) \mathrm{G}(\mathrm{T} / \mathrm{C})]$ and $3^{\prime}$ splice sites [(C/T)AG] typical of fungal genes (Bruchez et al. 1993). The ORF1 product has high similarity in amino acid sequence to 4-coumarate-CoA ligases of higher plants, acetyl-CoA ligases of microorganisms, long chain acyl-CoA synthetases of microorganisms, and luciferases of insects (Fig. 6). These enzymes have been identified as members of a superfamily, designated the carboxylactivating enzymes or the AMP-binding proteins (Fulda et al. 1994; Pavela-Vrancic et al. 1994). The ORF1 product contains the highly conserved stretch of amino acids (amino acid positions 205 to 224) found in the carboxyl-activating enzyme family (Fulda et al. 1994; Pavela-Vrancic et al. 1994) (Fig. 6). The conserved lysine residue (position 218) within this sequence has been proposed to be essential for catalysis (Pavela-Vrancic et al. 1994). The ORF1 product also contains a consensus sequence TGD (amino acid positions 436 to 438) for the putative ATP binding region (Pavela-Vrancic et al. 1994) (Fig. 6).

Transcription of ORF1 and confirmation of introns were tested by reverse transcription-polymerase chain reaction (RTPCR) experiments. RT-PCR amplification produced DNA fragments of the expected size from total RNA of the wild type (Fig. 7A-C). RT-PCR products were cloned in pGEM-T Easy and sequenced. Comparison of the genomic sequence with those of the RT-PCR products confirmed that the five introns are spliced.

ORF2 (786 bp) potentially encodes a 262 amino acid protein after splicing of one intron (Fig. 4). The ORF2 product has no similarity to known proteins in the data bases. RT-PCR amplification produced DNA fragments of the expected size from total RNA of the wild-type strain (Fig. 7D). Nucleotide sequencing of the products confirmed the presence of the intron in this region.

\section{Mutation of ORF1 and ORF2 in the wild type by targeted gene disruption.}

To assess the function of ORF1 and ORF2 in AK-toxin biosynthesis, fragments of the reading frames were cloned in pSH75 to produce targeting vectors pGDT1 and pGDT2 (Fig. 4). Transformation of the wild type with pGDT1 and pGDT2 yielded 12 out of 100 pGDT1 transformants and three out of 100 pGDT2 transformants that had completely lost AK-toxin production and pathogenicity. AK-toxin I and 9,10-epoxy-8hydroxy-9-methyl-decatrienoic acid in culture filtrates of a subset of toxin-producing $\left(\mathrm{Tox}^{+}\right)$and toxin-deficient $\left(\mathrm{Tox}^{-}\right)$ transformants were quantified by high-performance liquid chromatography. Toxin I was detected in culture filtrates of all $\mathrm{Tox}^{+}$transformants tested: 60 to $393 \mathrm{ng} \cdot \mathrm{ml}^{-1}$ in five pGDT1 transformants and 180 to $857 \mathrm{ng} \cdot \mathrm{ml}^{-1}$ in five pGDT2 transformants. Culture filtrates of $\mathrm{Tox}^{+}$transformants also contained 9,10-epoxy-8-hydroxy-9-methyl-decatrienoic acid: 274 to $514 \mathrm{ng} \cdot \mathrm{ml}^{-1}$ in pGDT1 transformants and 331 to $1,166 \mathrm{ng} \cdot \mathrm{ml}^{-1}$ in pGDT2 transformants. In contrast, the same analyses could detect neither toxin I nor 9,10-epoxy-8-hydroxy-9-methyl-decatrienoic acid in culture filtrates of five and three of Tox ${ }^{-}$transformants produced by pGDT1 and pGDT2, respectively.

The integration mode of the targeting vectors in these Tox $^{+}$ and Tox $^{-}$transformants was analyzed by DNA gel blot analysis (Fig. 8). Total DNA of the wild-type strain and pGDT1 transformants was digested with both HindIII and SphI, and the blot was probed with the ORF1 fragment in pGDT1. These enzymes have no site in pGDT1. On the basis of the restriction map of pcAKT-1, a 1.9-kb fragment was expected in the wild type (Fig. 4); however, the probe hybridized to two bands (1.9 and $2.3 \mathrm{~kb}$ ) (Fig. $8 \mathrm{~A}$ ). The 2.3-kb signal was more intense than that of the $1.9-\mathrm{kb}$ band, demonstrating that the wild-type strain contains multiple copies of the ORF1 homologue. All five $\mathrm{Tox}^{+}$transformants carried these two hybridizing bands (Fig. 8A). In contrast, the 1.9-kb hybridizing band was not detected in the Tox transformants (Fig. 8A). One of the Tox $^{-}$transformants also lost the $2.3-\mathrm{kb}$ band. The other Tox ${ }^{-}$transformants had the 2.3-kb bands, although their hybridizing signal was weaker than those of the wild type (Fig. $8 \mathrm{~A})$. These results suggest that the $1.9-\mathrm{kb}$ fragment represents the functional ORF1. Tox ${ }^{+}$and Tox transformants both carried high-molecular-weight hybridizing bands $(>23 \mathrm{~kb})$ with markedly intense signals, suggesting high-copy-number integration of plasmids as tandem repeats (Fig. 8A). Such integration has been observed in transformation of A. alternata with plasmids that contain or lack the fungal DNA (Tsuge et al. 1990; Shiotani and Tsuge 1995). To control for the relative amounts of DNA loaded in each lane, the same blot was subsequently stripped of the ORF1 probe and rehybridized with the 1.4-kb BamHI fragment in pBBR2 (Kawamura et al. 1999) as a single-copy gene probe (Fig. 8C). pBBR2 contains the $A$. alternata BRM2 gene involved in melanin biosynthesis (Kawamura et al. 1999). The BRM2 probe visualized single bands of the expected size in all lanes, indicating complete digestion of DNA (Fig. 8C). Although intensity of hybridization signal was not equal in all lanes, there were no lanes in which DNA was considerably overloaded or underloaded (Fig. 8C).

To confirm ORF1 disruption in $\mathrm{Tox}^{-}$transformants, the presence of ORF1 transcript was tested by RT-PCR with 
primers RT1-5 and RT1-6 (Figs. 4 and 8E). RT-PCR produced a DNA fragment of $0.69 \mathrm{~kb}$ from total RNA of the wild-type and $\mathrm{Tox}^{+}$transformants, but not from those of Tox ${ }^{-}$transformants (Fig. 8E).

Total DNA of pGDT2 transformants was digested with $P v u I I$, which has no site in pGDT2, and the blot was probed with the ORF2 fragment in pGDT2. The restriction map of pcAKT-1 predicts that the probe would hybridize to one 5.0kb $P v u$ II fragment in the wild type (Fig. 4); however, two bands (5.0 and $6.7 \mathrm{~kb}$ ) hybridized (Fig. 8B). The 6.7-kb signal was more intense than the other. Thus, there are also multiple copies of the ORF2 homologue in the wild type. All $\mathrm{Tox}^{+}$ transformants contained these two bands (Fig. 8B). All Tox ${ }^{-}$ transformants lacked the 5.0-kb bands (Fig. 8B). Rehybridization of the blot with the BRM2 probe showed that the relative amounts of DNA were not considerably different among lanes (Fig. 8D). An RT-PCR experiment with primers RT2-1 and RT2-2 (Fig. 4) confirmed ORF2 disruption in Tox ${ }^{-}$transformants: the expected $0.78-\mathrm{kb}$ DNA fragment was detected in wild-type and $\mathrm{Tox}^{+}$transformants, but not in $\mathrm{Tox}^{-}$transformants (Fig. 8F). These results imply that ORF2 on the $5.0-\mathrm{kb}$ $P v u \mathrm{II}$ fragment encodes the functional gene.

Since these gene disruption experiments demonstrated the essential roles of ORF1 and ORF2 in AK-toxin biosynthesis and pathogenicity, the genes encoding ORF1 and ORF2 were designated $A K T 1$ and $A K T 2$, respectively.

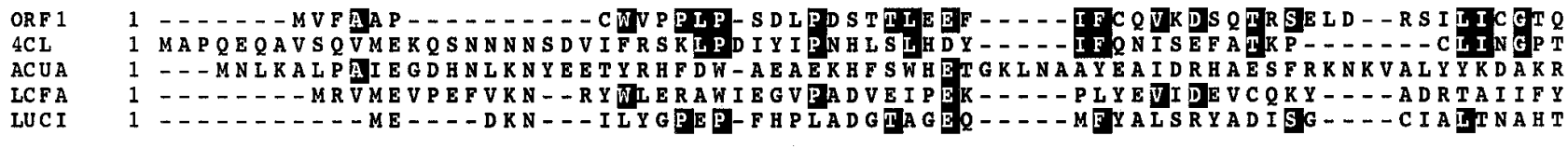

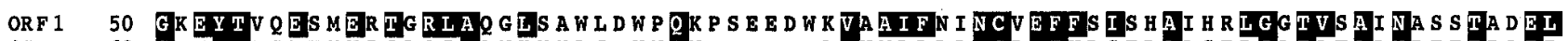

4CL 63 GHVYTSDVHVISRTAANFKLG-VNQN--- -DVVMLLLPNCPEFVLSFLAASFGATATAANPFFTPAI

ACUA 71 DEKYTFR EMKEESNRAGNVLRRYGNVEKG-- - DRVFIFMPRSPELYFTMLGAIKIGAIAGPLFEAFMEGAV

LCFA 56 GAEIKYGQLKEY TDRFATSLKMG-IKKG----DVVAIYSPNCPQFVIAYYGAMKAGATVIALSPLFAPREV

LUCI 47 KENVLYEEFLKSCRLAESFKKYG-LKQN----DTIAVCSENGLQEFLPLIASIYLGIIAAPVSDKYIEREL

ORF 124 GA 2LRL SNAQAIFTCNTLIKIAMKAS QKVGIPLANTF LTDAPGSYRPDDVYPFQEIDNIVRTARSSLPLLQLGR

4CL 130 AKQAKASNTKLITIEARYVDKIKPLQN- - DDGVVIVCIDDNESVPIPEGCLRETELTQSTTEASEVIDSVEISP

ACUA 139 KDRLENSEAKVVVITPELIERIPVDKLP-HLQHVFVVGGEAESGTNIINYDEAAKQ-ESTRLDIEWMD- - K -K

ICFA 123 GY QLNDSGAKVLVTVEQLYPNFAAVRENTGVEEVLVANIAGGEAKVEGKFRDFR EMLASP PEPPEVS- - -WNVK

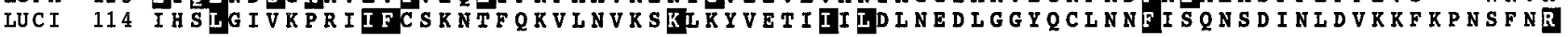

ORF 1198 GQGS TP AYI CESSGTS GA QKPVLLSHQGIIAN-

4CL 202 DD - V - - VALPYS S GTTGL PKGVMLTHKGLVT-_...

ACUA 207 DG-- - FILHYTS GSTGTPKGVLBVHEAMTQ

LCFA 194 DD - V- - AVLQYTGGTTGLPKAAMLTHYNVVANMYELIPFTDLIRGWLKSHKVIREEGDYVIVDLDGKEYRTFR

LUCI 188 DDQV-- ALVMFS GTTGVSKG VMLTHKNIVA--

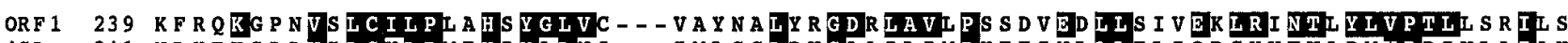

$4 C L 241$ NLYFHSDDVILCVLPMFIIYALNS-- IMLCGLRVGAAIIMPKFEINLLLELIQRCKVTVAPMVPPIVLAIAK

ACUA 241 VIDLREEDIYWCTADPGWVTGTVYG--IFAPWLNGATNVIVGGRFSP ESWYGTIEQLGVNVW YSAPTAFRMLMG

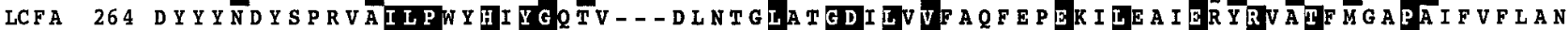

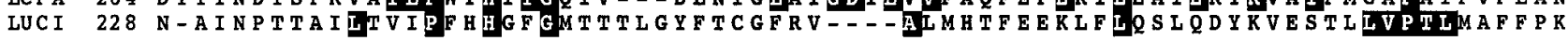

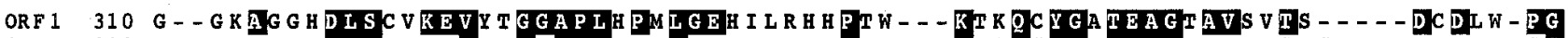

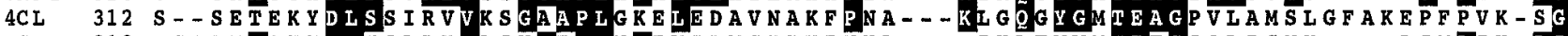

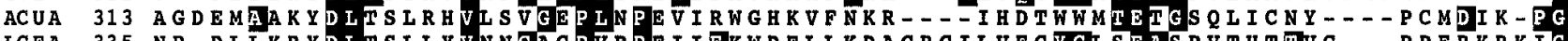

LCFA 335 NP-DLLKRYDLTSLLYVNGAGPVPPEIIEKWDELLKDAGRGILVEGYGLSEASPVTHTVG-DPPRKRKIG

LUCI 297 S- - ALVEKYDLSHLKEIAS GGAPLSKEI GEMVKKRFRLN- - FVR GGYGLTETTSAVLITP--- - DPDVR-PG

ORF 1373 SVGCLLPGVQAKI IRSDGSETTKHDESGELWVSS--PSLAIGYLSNPLATEATFTVDNTGRTWLRTGDEAKICL

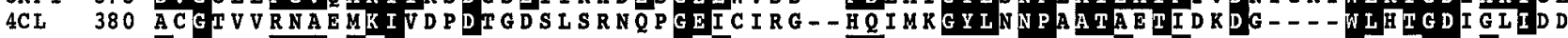

ACUA 378 SMGKPI PGVEAAIVD-NOGNELPPYRMGNLAIKKGWPSMMHTIWN NPEKYES YFMPGG-- - WYVSGDSAYMDE

LCFA 405 S VGPPIPNTYAAI INPETMEFLPIGEEGELVIAG--PQVMRGYWNRPRETEDVFFEAGG-MKWLRTGIARMDE

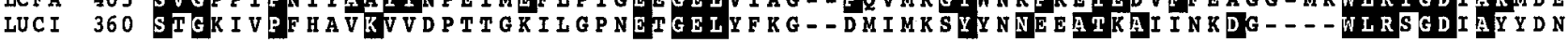

ORF 1445 S PNGNEHLF I D R I KDI I KVKGFQVAPVELEQLLLSNDFVEEVAI TSRQDKRGEERPQAFVVRTHEGLKEPQDA

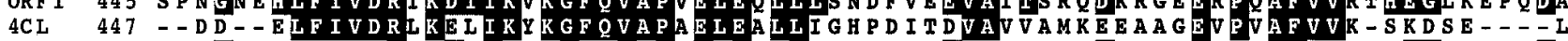

ACUA 446 - - EG- - Y FWF QGRVDDVIMTSGERVGPFEVESKLVEHPAIAEAGVIGKPDPVRGEIIKAFIAL-REGFEPS-DK

LCFA $475-$ - DG- - YFYI VDRLKDIIKYKGHSVYPREIEDIMYEHPAIKEVCVIGLPDEVAGETIKAFVVL-HEDYRGK--I

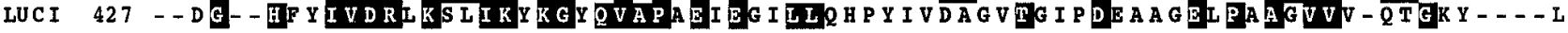

ORF 1519 VS ESL QALVKARKAR YKWLH PHVIFVDSLPKTTSGK IMRRALRN MCPANSEVNGRLSSKI

4CL 513 SEDDVKQFVSKQVVFYKRIN-KVFFTESTPKAPSGKILRKDLRAKLANGL_.......

ACUA 515 LKEEIRLFVKOGLAAHAAPR-E IEFKDKLPKTRSGK IMRRVL KAWELNLPAGDLSTMED-

LCFA 543 TEQD I INWCKERMAAYKY PR - I EER DELPKSAAGKYLRRILREEELKKMKR------ (27.8\%)

LUCI 493 NEQIVQNFVSSQVSTAKWIRGGVKFLDEIPKGSTGKIDRKVLRQMFEKHKSKL- - - - (27.6\%)

Fig. 6. Similarity of the ORF1-encoded protein with other proteins. Amino acid sequence of the ORF1-encoded protein was aligned with those of 4coumarate-CoA ligase of Arabidopsis thaliana (4CL) (Lee et al. 1995), acetyl-CoA ligase of Bacillus subtilis (ACUA) (Grundy et al. 1993), long chain acyl-CoA synthetase of Archaeoglobus fulgidus (LCFA) (Klenk et al. 1997), and luciferase of Photuris pennsylvanica (LUCI) (Ye et al. 1997) by the CLUSTAL W program (Thompson et al. 1994). Amino acids that are conserved between the ORF1 product and any of the others are ind icated as white letters on a black background. Amino acid identity between the ORF1 product and each of the others is shown in parentheses. The highly conserved stretch of 20 amino acids in the carboxyl-activating enzyme family (Fulda et al. 1994) and a consensus sequence TGD for the put ative ATP binding region (Pavela-Vrancic et al. 1994) are underlined. 


\section{Distribution of the $A K T 1$ and $A K T 2$ homologues \\ in $A$. alternata strains.}

DNA from 12 strains of the Japanese pear pathotype was digested with EcoRI, and the blot was hybridized with the $A K T 1$ - and $A K T 2$-specific probes p1EX and p2XS, respectively (Fig. 4). Each probe detected bands in all strains (Fig. 9). Use of other restriction enzymes showed that all strains carry multiple copies of the gene homologues (data not shown). Nineteen strains from an additional six pathotypes and five nonpathogenic strains of A. alternata were also analyzed for distribution of these gene homologues. Strains from the tangerine pathotype, which produces ACT-toxin (Fig. 1) (Pegg 1966; Kohmoto et al. 1993), and the strawberry pathotype, which produces AF-toxin (Fig. 1) (Maekawa et al. 1984; Nakatsuka et al. 1986), were found to have the AKT1 and AKT2 homologues (Fig. 9). However, strains from other pathotypes and nonpathogenic A. alternata had no detectable homologues of these genes (Fig. 9).

\section{DISCUSSION}

The REMI technique was used to mutagenize and simultaneously tag the genes required for AK-toxin biosynthesis of the Japanese pear pathotype of A. alternata. The presence of the restriction enzyme during transformation increased transformation frequency in A. alternata as reported by Akamatsu et al. (1997). Three Tox ${ }^{-}$, nonpathogenic mutants were isolated from 984 REMI transformants. This frequency (about $0.3 \%$ ) is considerably higher than would be expected with random integrations (Kang and Metzenberg 1993). This result

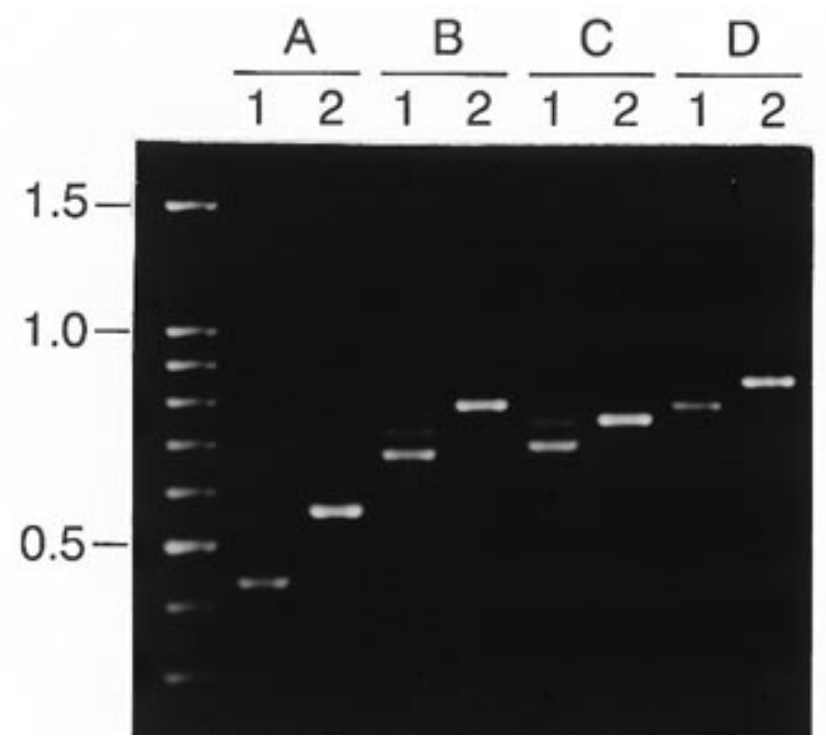

Fig. 7. Detection of ORF1 and ORF2 transcripts. Total RNA of wildtype strain $15 \mathrm{~A}$ was used as a template for reverse transcription (RT), and the synthesized cDNA was subjected to polymerase chain reaction (PCR) amplification (lane 1). Total DNA was also used as a template for PCR (lane 2). The PCR products were electrophoresed in a $1.2 \%$ agarose gel. Sizes (in kilobases) of marker DNA fragments (100-bp DNA ladder, Takara) are indicated on left. Primers for ORF1 (RT primer and PCR primer pair): RT1-2 and RT1-1/RT1-2 (A); RT14 and RT1-3/RT1-4 (B); RT1-6 and RT1-5/RT1-6 (C) (see Figure 4). Primers for ORF2 (RT primer and PCR primer pair): RT2-2 and RT21/RT2-2 (D) (see Figure 4). suggests that REMI-based insertions are not random in A. alternata, or that a large number of genes participate in AKtoxin biosynthesis.

The REMI technique has been reported to generate singlecopy integration events with high frequency, allowing efficient isolation of tagged genes (Kuspa and Loomis 1992; Lu et al. 1994; Bölker et al. 1995; Yang et al. 1996; Sweigard et al. 1998). However, in this study, DNA gel blot analysis of the three Tox ${ }^{-}$mutants showed more complex plasmid integration events. All three mutants contained multiple copies of plasmid DNA. In other fungi, digestion of DNA of REMI transformants with the restriction enzyme used in REMI frequently produces a fragment equal to the size of the inserted plasmid (Schiestl and Petes 1991; Lu et al. 1994; Bölker et al. 1995; Shi et al. 1995). However, HindIII, which was used in REMI transformation of the Japanese pear pathotype, produced bands larger than $5.5 \mathrm{~kb}$ (the size of pSH75) in every mutant. Nucleotide sequencing of the junction of plasmid and genomic DNA recovered from mutant ATA95-1 demonstrated the deletion of eight terminal nucleotides of integrated plasmid. These results indicate that the HindIII sites at the junctions of plasmid and genomic DNA were lost during plasmid integration in these mutants. The addition of restriction enzyme to transformation mixture markedly enhanced transformation efficiency, probably by promotion of plasmid integration into host chromosomes. We assume that plasmid DNA is predominantly integrated into digested restriction enzyme sites. However, the REMI plasmid integration process is more complicated in $A$. alternata than in other fungi. A complex REMI process was also reported in Mycosphaerella zeae-maydis, which produces a host-specific toxin known as PM-toxin (Yun et al. 1998). Yun et al. (1998) isolated toxin-deficient mutants of this pathogen by REMI transformation. Analysis of the plasmid insertion sites of mutants showed that the REMI procedure can cause deletions (Yun et al. 1998).

We recovered DNA flanking the plasmid insertion point of mutant ATA95-1. With the recovered DNA used as a probe, a cosmid clone, pcAKT-1, was isolated from a genomic library of the wild type. We identified two genes, AKT1 and AKT2, in an $8.0-\mathrm{kb}$ region corresponding to the plasmid integration site in the mutant. Their essential roles in AK-toxin biosynthesis were proven by targeted disruption, which caused complete loss of toxin production and pathogenicity. Loss of pathogenicity in the gene-targeted strains confirms that AK-toxin is an essential factor in pathogenicity of the Japanese pear pathotype.

We observed that REMI mutant ATA95-1 and AKT1- or AKT2-targeted mutants failed to produce not only AK-toxin but also 9,10-epoxy-8-hydroxy-9-methyl-decatrienoic acid, which has been identified as a precursor of AK-toxin (Feng et al. 1990; Nakatsuka et al. 1990). This result indicates that $A K T 1$ and $A K T 2$ are involved in 9,10-epoxy-8-hydroxy-9methyl-decatrienoic acid biosynthesis. The putative AKT2encoded protein shows no homology to any known proteins. The amino acid sequence of the $A K T 1$ product, however, has significant similarity to those of 4-coumarate-CoA ligases, acetyl-CoA ligases, long chain acyl-CoA synthetases, and luciferases. The first three play crucial roles in different pathways and subcellular compartments involved in lipid metabolism by a similar reaction mechanism: formation of an acyl adenylate from ATP and a fatty acid or acetate, and then trans- 
fer of the acyl group to the sulfhydryl group of CoA, with simultaneous release of AMP (Fulda et al. 1994). These enzymes have been identified as members of a superfamily of carboxyl-activating enzymes or AMP-binding proteins (Fulda et al. 1994; Pavela-Vrancic et al. 1994). Based on sequence similarity, luciferase has been also identified as a member of this family (Fulda et al. 1994). Common to all enzymes belonging to this family is the activation of the carboxyl group at the expense of ATP. Thus, the AKT1 product is likely to activate an earlier precursor of 9,10-epoxy-8-hydroxy-9methyl-decatrienoic acid for further modification by other enzymes.

The AKT1 and AKT2 homologues are found not only in the Japanese pear pathotype strains but also in strains of the tangerine and strawberry pathotypes. The presence of the homologous genomic DNA in these three pathotypes is consistent with the similarity of their host-specific toxins and their host specificity (Fig. 1). Their toxins have a common moiety, 9,10-epoxy-8-hydroxy-9-methyl-decatrienoic acid (Fig. 1) (Nakashima et al. 1985; Nakatsuka et al. 1986; Kohmoto et al.
1993). These pathotypes should share the genes encoding the enzymes for biosynthesis of the common moiety.

The Japanese pear pathotype is pathogenic only to susceptible pear cultivars (Tanaka 1933; Otani et al. 1985). The tangerine pathotype has been identified as a causal agent of brown spot of tangerines and mandarins, and has not occurred in Japan so far (Pegg 1966; Kohmoto et al. 1993). The strawberry pathotype has been identified as a causal agent of Alternaria black spot of strawberry (Maekawa et al. 1984). Interestingly, these two pathotypes were found pathogenic also to Japanese pear cultivars susceptible to the Japanese pear pathotype (Maekawa et al. 1984; Kohmoto et al. 1993). The host ranges of these pathotypes can be explained by toxicity of their host-specific toxins. Each of these toxins consists of multiple, related molecules (Fig. 1). AK-toxins I and II are toxic only to Japanese pear (Nakashima et al. 1985; Otani et al. 1985). ACT-toxin I is toxic to both tangerine and pear; toxin II is more toxic to pear than to tangerine (Kohmoto et al. 1993). AF-toxin I is toxic to both strawberry and pear; toxin II is toxic only to pear; toxin III is more toxic to strawberry than
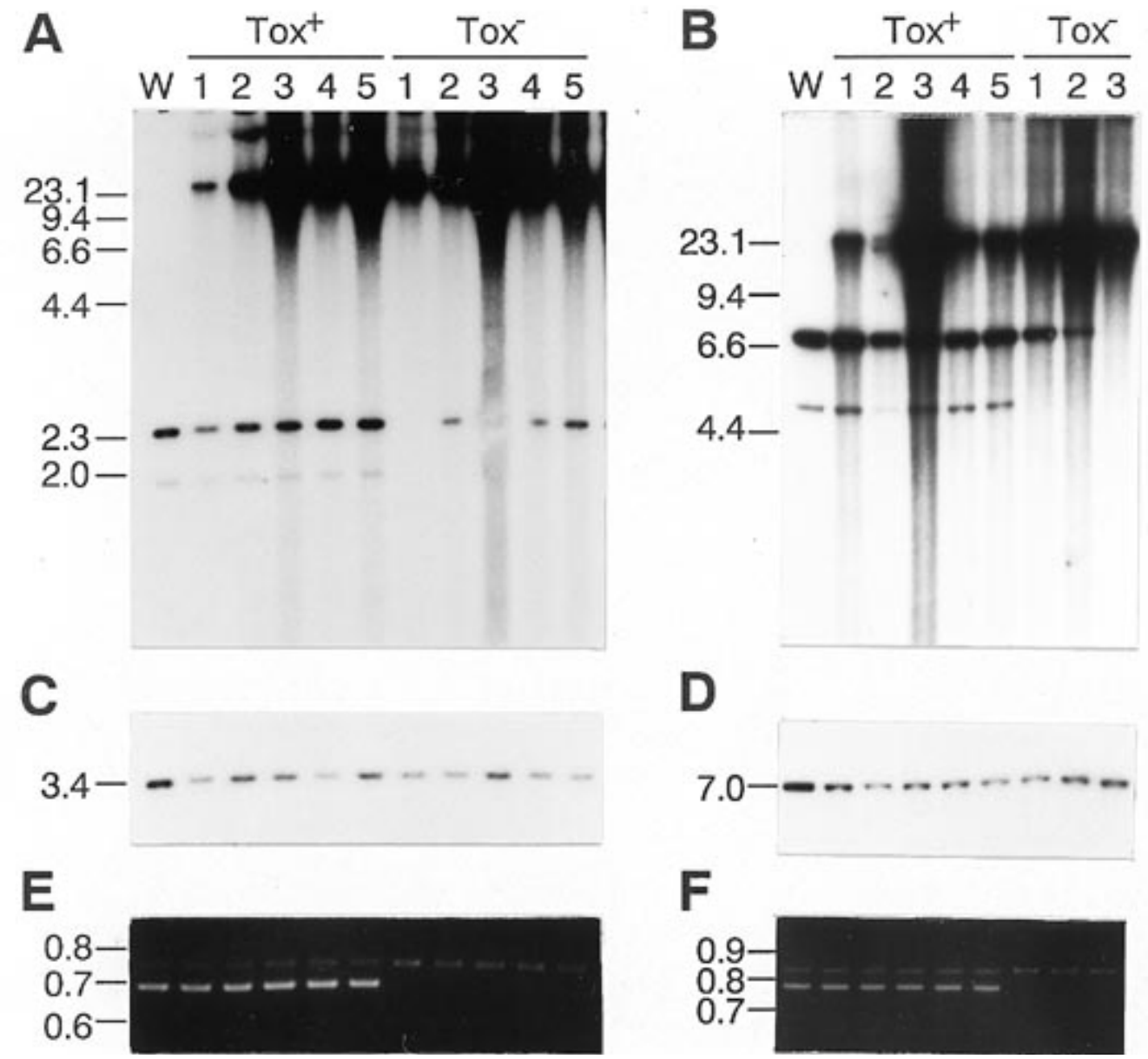

Fig. 8. DNA gel blot and reverse transcription-polymerase chain reaction (RT-PCR) analyses of (A, C, and E) pGDT1 and (B, D, and F) pGDT2 transformants. A and B, Total DNA from wild-type strain 15A (W), toxin-producing (Tox ${ }^{+}$), or toxin-deficient (Tox $\left.{ }^{-}\right)$transformants was digested with (A) HindIII-SphI or (B) $P v u I I$ and fractionated in an $0.8 \%$ agarose gel. Blots were probed with (A) the ORF1 fragment in pGDT1 or (B) the ORF2 fragment in pGDT2 (see Figure 4). Sizes (in kilobases) of marker DNA fragments (HindIII-digested $\lambda$ DNA) are indicated on left. C and D, Blots of $\mathbf{A}$ and $\mathbf{B}$ were stripped of the probes and rehybridized with the 1.4-kb BamHI fragment in pBBR2, which contains the Alternaria alternata BRM2 gene involved in melanin biosynthesis (Kawamura et al. 1999). E and F, Total RNA was used as a template for RT, and the synthesized cDNA was subjected to PCR amplification. PCR products were electrophoresed in a 1.2\% agarose gel. RT primer and PCR primer pair: RT1-6 and RT1-5/RT1-6 (E); RT2-2 and RT21/RT2-2 (F) (see Figure 4). 
to pear (Maekawa et al. 1984; Nakatsuka et al. 1986). The crucial roles of $A K T 1$ and $A K T 2$ in AK-toxin biosynthesis might be characterized by chemical and biochemical analyses of production and accumulation of toxin-related metabolites in the Tox ${ }^{-}$mutants.

Our results show that these three pathotypes are good models for studying intraspecific variation and evolution of pathogenicity in A. alternata. Strains from other pathotypes and nonpathogenic $A$. alternata have no detectable homologue of $A K T 1$ and $A K T 2$, suggesting that the evolution of toxin production in these three pathotypes may involve horizontal transfer of DNA. Horizontal transfer of the genes required for host-specific toxin biosynthesis has been proposed for HCtoxin of Cochliobolus carbonum race 1 (Nikolskaya et al. 1995; Ahn and Walton 1996) and T-toxin of C. heterostrophus race T (Yang et al. 1996; Yoder 1998). Isolation and characterization of the AKT1 and AKT2 homologues from the tangerine and strawberry pathotypes are now in progress.

DNA gel blot analysis indicates that the Japanese pear pathotype strain 15A has additional gene homologues of AKT1 and $A K T 2$. DNA gel blot analysis showed that other strains of the pathotype also contain multiple copies of these gene homologues. The complexity of the genetic loci controlling host-specific toxin biosynthesis has been reported for C. carbonum (Panaccione et al. 1992; Ahn and Walton 1996, 1997; Pitkin et al. 1996; Walton et al. 1998) and C. heterostrophus (Tzeng et al. 1992; Chang and Bronson 1996; Yoder 1998; Kodama et al. 1999). Characterization of the structure and chromosomal distribution of the AKT1 and AKT2 homologues in the Japanese pear pathotype strains is of great importance in the study of evolution of AK-toxin biosynthesis and origin of genes for toxin biosynthesis. Recently, it has been discovered that genes for certain types of metabolic pathways are clustered in filamentous fungi (Keller and Hohn 1997). There is a possibility that $A K T 1$ and $A K T 2$ are clustered with additional genes required for AK-toxin biosynthesis. Structural and functional analyses of the regions flanking these genes are worthy of further study.

\section{MATERIALS AND METHODS}

\section{Fungal strains.}

A total of 36 strains, consisting of 31 strains from seven pathotypes of A. alternata and five strains from nonpathogenic A. alternata, were used in this study. Strain $15 \mathrm{~A}$ of the Japanese pear pathotype was used for REMI transformation and

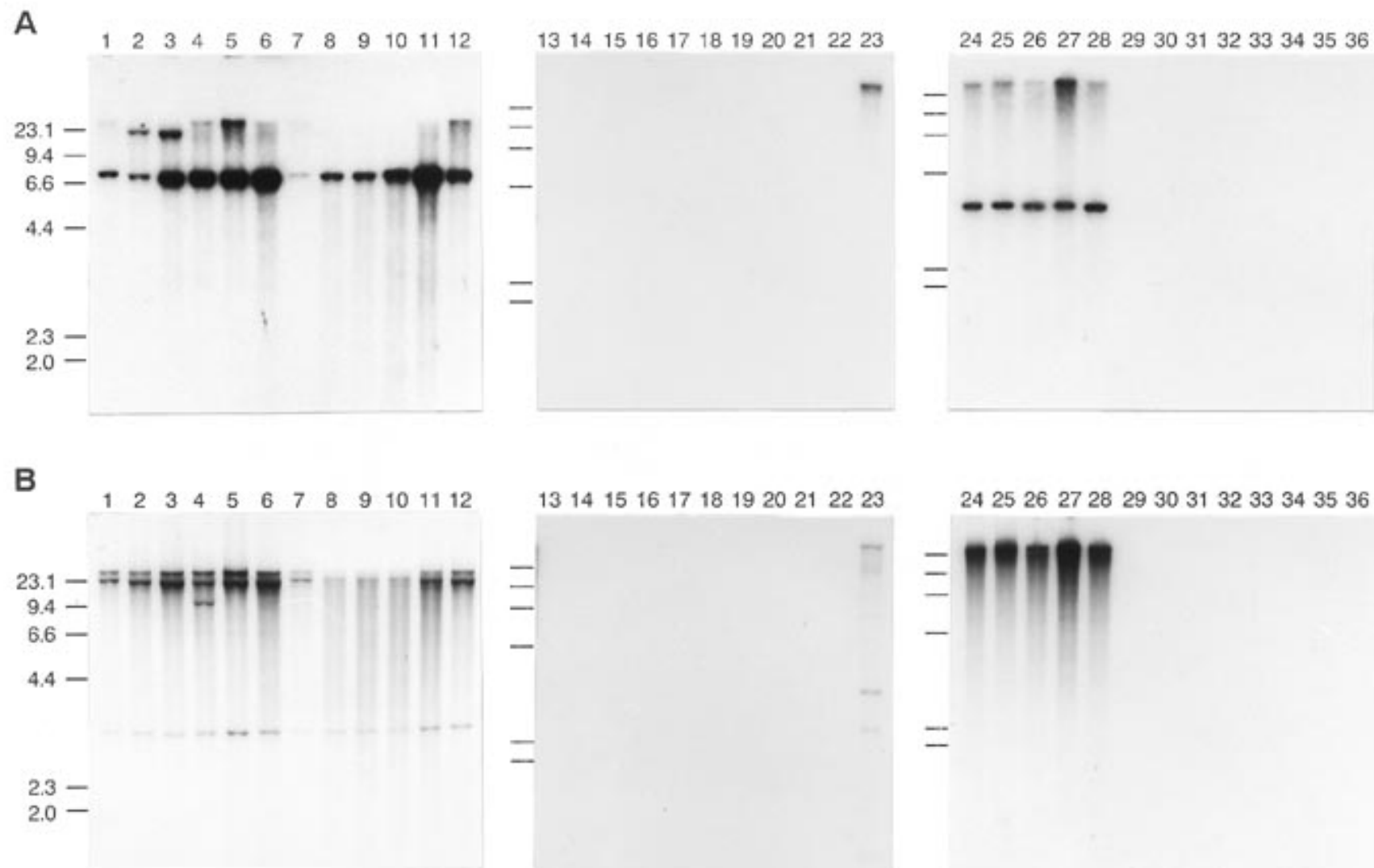

Fig. 9. Distribution of the $A K T 1$ and $A K T 2$ homologues in strains of Alternaria alternata. Total DNA of each strain was digested with EcoRI and separated in an $0.8 \%$ agarose gel. Blots were probed with (A) p1EX or (B) p2XS (see Figure 4). Sizes (in kilobases) of marker DNA fragments (HindIIIdigested $\lambda$ DNA) are indicated on left. Lanes 1 to 12, strains 15A, T88-11, T88-52, T88-58, T88-107, 91H-18, 91H-27, Nu89-22, N18, G16, G31, and G90-A2 of the Japanese pear pathotype; lanes 13 to 16, strains AM-1, IFO08984, Ku-16Ro, and AM91-1 of the apple pathotype (AM-toxin producer); lanes 17 to 21, strains AT-204, IFO6149, no. 122-2, 86-1, and ATL-10 of the tobacco pathotype (AT-toxin producer); lane 22, strain ATCC38962 of the rough lemon pathotype (ACR-toxin producer); lane 23, strain ATCC38963 of the tangerine pathotype (ACT-toxin producer); lanes 24 to 28, strains O187, M-30, T-32, NAF-2, and NAF-3 of the strawberry pathotype (AF-toxin producer); lanes 29 to 31, strains AL-4, AL-12, and no. 91080804 of the tomato pathotype (AAL-toxin producer); lanes 32 to 36, strains IFO031188, IFO031189, ATCC66981, ATCC66982, and O-94 of nonpathogenic A. alternata (Kusaba and Tsuge 1995). 
isolation of the $A K T 1$ and $A K T 2$ genes. The other strains were used for analysis of distribution of the gene homologues. Strains were routinely maintained on potato dextrose agar (PDA; Difco, Detroit, MI).

\section{Plasmids and genomic libraries.}

Integrative transformation vector $\mathrm{pSH} 75$ was used for transformation of A. alternata (Kimura and Tsuge 1993). pSH75 carries the $h p h$ gene, which is regulated by the Aspergillus nidulans $\operatorname{trpC}$ promoter and terminator sequences, in pSP72 (Promega, Madison, WI) (Cullen et al. 1987; Kimura and Tsuge 1993). The 1.1-kb EcoRI-XhoI fragment internal to AKT1 was cloned in pBluescript $\mathrm{KS}^{+}$(Stratagene, La Jolla, CA) to produce p1EX (Fig. 4). The 1.1-kb insert was cut out from p1EX by digestion with BamHI and XhoI and cloned in the BamHI-XhoI site of pSH75 to produce the targeted disruption vector pGDT1 (Fig. 4). The 0.9-kb fragment internal to AKT2 was amplified from pcAKT-1 by PCR with primers ORF2-X (5'-TTCTCGAGATCATGCGGACGAT-3') and ORF2-S (5'-TTGCATGCTCATCTCCTTGCT-3') (Fig. 4). ORF2-X and ORF2-S included XhoI and SphI sites (underlined), respectively, flanking the $A K T 2$ sequences. The PCR mixture $(50 \mu \mathrm{l})$ contained $1 \mathrm{ng}$ of pcAKT-1, $1 \mu \mathrm{M}$ concentrations of each primer, $200 \mu \mathrm{M}$ deoxyribonucleotide triphosphate and $1.25 \mathrm{U}$ of Taq DNA polymerase (Takara, Ohtsu, Japan) with buffer from the manufacturer. PCR was performed for 25 cycles with an initial $3 \mathrm{~min}$ at $94^{\circ} \mathrm{C}$ for denaturation. Each cycle consisted of $1 \mathrm{~min}$ at $94^{\circ} \mathrm{C}, 30 \mathrm{~s}$ at $60^{\circ} \mathrm{C}$, and $1 \mathrm{~min}$ at $72^{\circ} \mathrm{C}$. The PCR product was cloned in pGEM-T Easy vector (Promega) to produce p2XS (Fig. 4). The PCR product was digested with $X h o I$ and $S p h I$, and then cloned in the XhoI-SphI site of pSH75 to produce the targeted disruption vector pGDT2 (Fig. 4). Plasmid pBBR2 contains the A. alternata BRM2 gene, which encodes 1,3,8-trihydroxynaphthalene reductase involved in melanin biosynthesis (Kawamura et al. 1999).

Genomic DNA of each Tox ${ }^{-}$mutant was partially digested with Sau3AI to generate fragments of 15 to $20 \mathrm{~kb}$ and cloned in the $\lambda$ DASHII vector (Stratagene) to construct a genomic library. A genomic cosmid library of wild-type strain 15A has been previously described (Kimura and Tsuge 1993). Screening of the libraries by plaque or colony hybridization was conducted by the standard methods (Sambrook et al. 1989).

\section{Fungal transformation.}

Protoplast preparation and transformation of A. alternata were performed by the methods previously described (Tsuge et al. 1990). For REMI, pSH75 was completely digested with BamHI or HindIII, and enzymes were removed by phenol extraction and ethanol precipitation (Sambrook et al. 1989). The digested DNA $(5 \mu \mathrm{g})$ was resuspended in $100 \mu \mathrm{l}$ of restriction enzyme buffer containing the enzyme used to linearize the plasmid and mixed with about $1 \times 10^{7}$ protoplasts in $100 \mu \mathrm{l}$ of STC (1.2 M sorbitol, $10 \mathrm{mM}$ Tris-HCl [pH 7.5], and $10 \mathrm{mM}$ $\mathrm{CaCl}_{2}$ ). The mixture was kept on ice for $10 \mathrm{~min}$ before addition of polyethylene glycol and completion of the usual transformation and plating protocols (Tsuge et al. 1990). As controls, circular plasmid DNA $(5 \mu \mathrm{g})$ or enzyme-digested DNA $(5 \mu \mathrm{g})$ was suspended in $100 \mu \mathrm{l}$ of restriction enzyme buffer without enzyme and subjected to transformation protocols. Colonies that appeared 5 to 10 days after plating on the selec- tive regeneration media were transferred to PDA containing hygromycin B (Wako Pure Chemicals, Osaka, Japan) at 100 $\mu \mathrm{g}$ per $\mathrm{ml}$, and transformants were selected 5 days after incubation at $25^{\circ} \mathrm{C}$.

\section{Screening and characterization of Tox ${ }^{-}$mutants.}

Transformants were grown on PDA containing hygromycin $\mathrm{B}$ at $100 \mu \mathrm{g}$ per $\mathrm{ml}$ for 5 days, and then agar blocks (about 20 $\mathrm{mm}^{3}$ ) bearing cultured mycelia were cut from the media. Detached young leaves of the susceptible cultivar Nijisseiki of Japanese pear were slightly wounded at the center of lamina with needle. An agar block was placed on the wounded portion of each leaf, and one drop of distilled water was added. After incubation at $25^{\circ} \mathrm{C}$ for $20 \mathrm{~h}$, pathogenicity was evaluated: a characteristic veinal necrosis was caused on leaves by pathogenic transformants, but not by nonpathogenic candidates. Nonpathogenic candidates were further tested for pathogenicity by spray inoculation of spore suspensions (about $5 \times 10^{5}$ spores per $\mathrm{ml}$ ) on Nijisseiki pear leaves as previously described (Hayashi et al. 1990).

AK-toxin production during growth in potato dextrose broth (PDB) (Difco) and during spore germination was tested by bioassay with Nijisseiki leaves and by reverse-phase highperformance liquid chromatography analysis as previously described (Hayashi et al. 1990). For high-performance liquid chromatography analysis, toxin in culture filtrates and spore germination fluids was extracted with ethyl acetate by the method of Katsuya et al. (1997), and toxin in mycelia was extracted by immersing mycelia in methanol for $24 \mathrm{~h}$ at $20^{\circ} \mathrm{C}$. The methanol extracts were concentrated under reduced pressure and subjected to the analysis. For bioassay, culture filtrates and spore germination fluids were dropped on the wounded portion of Nijisseiki leaves. Methanol extracts of mycelia were evaporated to dryness under reduced pressure. The residue was dissolved in a small amount of acetone, diluted with water to give an acetone concentration at less than $5 \%$, and applied to Nijisseiki leaves. Ethyl acetate extracts of culture filtrates were also used for analysis of production of 9,10-epoxy-8-hydroxy-9-methyl-decatrienoic acid by reversephase high-performance liquid chromatography as previously described (Feng et al. 1990).

Prototrophy was tested on a minimal medium (10 $\mathrm{g}$ of $\mathrm{KNO}_{3}, 5 \mathrm{~g}$ of $\mathrm{KH}_{2} \mathrm{PO}_{4}, 2.5 \mathrm{~g}$ of $\mathrm{MgSO}_{4} \cdot 7 \mathrm{H}_{2} \mathrm{O}, 0.02 \mathrm{~g}$ of $\mathrm{FeCl}_{3}, 10 \mathrm{~g}$ of glucose, $20 \mathrm{~g}$ of agar per liter). Vegetative growth and sporulation was assayed by the method of Kawamura et al. (1999).

\section{Nucleic acid extraction.}

For extraction of DNA, fungi were grown in $50 \mathrm{ml}$ of $\mathrm{PDB}$ in $100-\mathrm{ml}$ Erlenmeyer flasks at $25^{\circ} \mathrm{C}$ for 3 days on an orbital shaker (120 rpm; Bio-Shaker BR-30LF; Taitec, Saitama, Japan). The resulting mycelia were ground in liquid nitrogen in a mortar with a pestle. Total cellular DNA was prepared from the powdered mycelia as previously described (Adachi et al. 1993). For extraction of RNA, fungi were grown on PDA at $25^{\circ} \mathrm{C}$ for 4 days. Mycelia were ground in liquid nitrogen in a mortar with a pestle. Total cellular RNA was extracted from the powdered mycelia as described by Timberlake (1986). Plasmid DNA, cosmid DNA, and recombinant $\lambda$ phage DNA were isolated by the standard methods (Sambrook et al. 1989). 


\section{Nucleic acid hybridization.}

Restriction enzyme digestion of DNA and fractionation in agarose gels were performed by the standard methods (Sambrook et al. 1989). Fractionated DNA was transferred to Hybond $\mathrm{N}^{+}$nylon membranes (Amersham, Arlington Heights, IL) and subjected to hybridization according to the manufacturer's recommendations. Hybridized blots were washed at $65^{\circ} \mathrm{C}$; the final wash was done in $1 \times$ SSPE $(1 \times$ SSPE is 180 $\mathrm{mM} \mathrm{NaCl}, 10 \mathrm{mM} \mathrm{NaH} \mathrm{PO}_{4}$ [pH 7.7], and $1 \mathrm{mM}$ EDTA) plus $0.1 \%$ sodium dodecyl sulfate. DNA probes were labeled with $\left[\alpha{ }^{32} \mathrm{P}\right] \mathrm{dCTP}$ (ICN Biochemicals, Costa Mesa, CA) by the random-primer method (Feinberg and Vogelstein 1983).

\section{RT-PCR analysis.}

RT-PCR was performed with the RNA PCR Kit Ver. 2 (Takara). The RT reaction mixture $(20 \mu \mathrm{l})$ contained $1 \mu \mathrm{g}$ of total RNA, $2.5 \mu \mathrm{M}$ primer, $1 \mathrm{mM}$ deoxyribonucleotide triphosphate and $5 \mathrm{U}$ of AMV reverse transcriptase XL with buffer from the manufacturer. The mixture was incubated at $55^{\circ} \mathrm{C}$ for $30 \mathrm{~min}$, and the enzyme was inactivated at $99^{\circ} \mathrm{C}$ for 5 min. For subsequent PCR, the mixture was added with 20 pmol of each primer, $2.5 \mathrm{U}$ of Taq DNA polymerase, buffer from the manufacturer, and water to a final volume of $100 \mu$ l. The PCR was performed for 25 cycles with an initial $3 \mathrm{~min}$ at $94^{\circ} \mathrm{C}$ for denaturation. Each cycle consisted of $30 \mathrm{~s}$ at $94^{\circ} \mathrm{C}$, $30 \mathrm{~s}$ at $60^{\circ} \mathrm{C}$, and $1 \mathrm{~min}$ at $72^{\circ} \mathrm{C}$. The following primers were used: RT1-1 (5'-TATCGCCTGAGTACATGCGT-3'), RT1-2 (5'-GCATGTGAAGATAGCCTGTG-3'), RT1-3 (5'-CACAG GCTATCTTCACATGC-3'), RT1-4 (5'-CGTAGCTCCATAG CATTGCT-3'), RT1-5 (5'-AGCAATGCTATGGAGCTACG$\left.3^{\prime}\right)$ and RT1-6 (5'-CTATATCTTGCTCGACAGCC-3') for ORF1 (Fig. 4); RT2-1 (5'-AGATGCAGCAGCCCATCATT-3') and RT2-2 (5'-CGACTGCAGATATTTCATCC-3') for ORF2 (Fig. 4). Primer combinations used in RT-PCRs are indicated in Figures 7 and 8. For analysis of nucleotide sequences, RTPCR products were cloned in pGEM-T Easy.

\section{Nucleotide sequence analysis.}

DNA was cloned in pBluescript $\mathrm{KS}^{+}$or pGEM-T Easy. DNA sequence information was obtained from both strands with the PRISM Dye Termination Cycle Sequencing Ready Reaction Kit (Applied Biosystems, Warrington, UK) and an automated fluorescent DNA sequencer (Model 373A, Applied Biosystems) according to the manufacturer's instructions. DNA sequences were analyzed with BLAST (Altschul et al. 1990). Amino acid alignments were made with the CLUSTAL W program (Thompson et al. 1994).

\section{ACKNOWLEDGMENTS}

We express our special thanks to Gillian Turgeon and Olen C. Yoder for their critical suggestions and encouragement to conduct this work and for critical reading of the manuscript. We thank Kazuya Akimitsu for critical suggestions and discussion; Motoichiro Kodama, Hirokazu Kobayashi, Hirofumi Yoshioka, Kazuhito Kawakita, and Noriyuki Doke for valuable suggestions; and the Radioisotope Research Center, Nagoya University, for technical assistance. This work was supported by grants-in-aid from the Ministry of Education, Science, Sports and Culture of Japan.

\section{LITERATURE CITED}

Adachi, Y., Watanabe, H., Tanabe, K., Doke, N., Nishimura, S., and Tsuge, T. 1993. Nuclear ribosomal DNA as a probe for genetic vari- ability in the Japanese pear pathotype of Alternaria alternata. Appl. Environ. Microbiol. 59:3197-3205.

Ahn, J.-H., and Walton, J. D. 1996. Chromosomal organization of TOX2, the complex locus controlling host-selective toxin biosynthesis in Cochliobolus carbonum. Plant Cell 8:887-897.

Ahn, J.-H., and Walton, J. D. 1997. A fatty acid synthase gene in Cochliobolus carbonum required for production of HC-toxin, cyclo(Dprolyl-L-alanyl-D-alanyl-L-2-amino-9,10-epoxi-8-oxodecanoyl). Mol. Plant-Microbe Interact. 10:207-214.

Akamatsu, H., Itoh, Y., Kodama, M., Otani, H., and Kohmoto, K. 1997. AAL-toxin deficient mutants of Alternaria alternata tomato pathotype by restriction enzyme-mediated integration. Phytopathology 87:967-972.

Altschul, S. F., Gish, W., Miller, W., Myers, E. W., and Lipman, D. J. 1990. Basic local alignment sequence tool. J. Mol. Biol. 215:403-410.

Bölker, M., Böhnet, H. U., Braun, K. H., Görl, J., and Kahmann, R. 1995. Tagging pathogenicity genes in Ustilago maydis by restriction enzyme-mediated integration (REMI). Mol. Gen. Genet. 248:547-552.

Bruchez, J. J. P., Eberle, J., and Russo, V. E. 1993. Regulatory sequences in the transcription of Neurospora crassa gene: CAAT box, TATA box, intron, poly(A) tail formation sequences. Fungal Genet. Newsl. 40:89-96.

Chang, H.-R., and Bronson, C. R. 1996. A reciprocal translocation and possible insertion(s) tightly associated with host-specific virulence in Cochliobolus heterostrophus. Genome 39:549-557.

Cullen, D., Leong, S. A., Wilson, L. J., and Henner, D. J. 1987. Transformation of Aspergillus nidulans with the hygromycin-resistance gene, $h p h$. Gene 57:21-26.

Dobinson, K. F., Harris, R. E., and Hamer, J. E. 1993. Grasshopper, a long terminal repeat (LTR) retroelement in the phytopathogenic fungus Magnaporthe grisea. Mol. Plant-Microbe Interact. 6:114-126.

Farman, M. L., Tosa, Y., Nitta, N., and Leong, S. A. 1996. MAGGY, a retrotransposon in the genome of the rice blast fungus Magnaporthe grisea. Mol. Gen. Genet. 251:665-674.

Feinberg, A. P., and Vogelstein, B. 1983. A technique for radiolabeling DNA restriction endonuclease fragments to high specific activity. Anal. Biochem. 136:6-13.

Feng, B.-N., Nakatsuka, S., Goto, T., Tsuge, T., and Nishimura, S. 1990. Biosynthesis of host-selective toxins produced by Alternaria alternata pathogens. I. (8R,9S)-9,10-epoxy-8-hydroxy-9-methyl-deca(2E,4Z,6E)-trienoic acid as a biological precursor of AK-toxins. Agric. Biol. Chem. 54:845-848.

Fulda, M., Heinz, E., and Wolter, F. P. 1994. The fadD gene of Escherichia coli $\mathrm{K} 12$ is located close to rnd at $39.6 \mathrm{~min}$ of the chromosomal map and is a new member of the AMP-binding protein family. Mol. Gen. Genet. 242:241-249.

Grundy, F. J., Water, D. A., Takova, T. Y., and Henkin, T. M. 1993. Identification of genes involved in utilization of acetate and acetoin in Bacillus subtilis. Mol. Microbiol. 10:259-271.

Hayashi, N., Tanabe, K., Tsuge, T., Nishimura, S., Kohmoto, K., and Otani, H. 1990. Determination of host-selective toxin production during spore germination of Alternaria alternata by high-performance liquid chromatography. Phytopathology 80:1088-1091.

Kang, S., and Metzenberg, R. L. 1993. Insertional mutagenesis in Neurospora crassa: Cloning and molecular analysis of the preg+ gene controlling the activity of the transcriptional activator NUC-1. Genetics 133:193-202.

Katsuya, S., Kaneko, I., Owaki, M., Ishikawa, K., Tsujimoto, T., and Tsuge, T. 1997. Circular DNA plasmid in the phytopathogenic fungus Alternaria alternata: Its temperature-dependent curing and association with pathogenicity. Genetics 146:111-120.

Kawamura, C., Tsujimoto, T., and Tsuge, T. 1999. Targeted disruption of a melanin biosynthesis gene affects conidial development and UV tolerance in the Japanese pear pathotype of Alternaria alternata. Mol. Plant-Microbe Interact. 12:59-63.

Keller, N. P., and Hohn, T. M. 1997. Metabolic pathway gene clusters in filamentous fungi. Fungal Genet. Biol. 21:17-29.

Kimura, N., and Tsuge, T. 1993. Gene cluster involved in melanin biosynthesis of the filamentous fungus Alternaria alternata. J. Bacteriol. 175:4427-4435.

Klenk, H. P., Clayton, R. A., Tomb, J. F., White, O., Nelson, K. E., Ketchum, K. A., Dodson, R. J., Gwinn, M., Hickey, E. K., Peterson, J. D., Richardson, D. L., Kerlavage, A. R., Graham, D. E., Kyrpides, N. C., Fleischmann, R. D., Quackenbush, J., Lee, N. H., Sutton, G., Gill, 
S., Kirkness, E. F., Dougherty, B. A., McKenney, K., and Adams, M. D. 1997. The complete genome sequence of the hyperthermophilic, sulphate-reducing archaeon Archaeoglobus fulgidus. Nature 390:364370.

Kodama, M., Rose, M. S., Yang, G., Yun, S. H., Yoder, O. C., and Turgeon, B. G. 1999. The translocation-associated Toxl locus of Cochliobolus heterostrophus is two genetic elements on two different chromosomes. Genetics 151:585-596.

Kohmoto, K., Itoh, Y., Shimomura, N., Kondoh, Y., Otani, H., Kodama, M., Nishimura, S., and Nakatsuka, S. 1993. Isolation and biological activities of two host-specific toxins from the tangerine pathotype of Alternaria alternata. Phytopathology 83:495-502.

Kohmoto, K., Otani, H., and Tsuge, T. 1995. Alternaria alternata pathogens. Pages 51-63 in: Pathogenesis and Host Specificity in Plant Diseases: Histopathological Biochemical, Genetic and Molecular Bases, Vol. II. Eukaryotes. K. Kohmoto, U. S. Singh, and R. P. Singh, eds. Pergamon, Oxford.

Kusaba, M., and Tsuge, T. 1994. Nuclear ribosomal DNA variation and pathogenic specialization in Alternaria fungi known to produce hostspecific toxins. Appl. Environ. Microbiol. 60:3055-3062.

Kusaba, M., and Tsuge, T. 1995. Phylogeny of Alternaria fungi known to produce host-specific toxins on the basis of variation in internal transcribed spacers of ribosomal DNA. Curr. Genet. 28:491-498.

Kusaba, M., and Tsuge, T. 1997. Mitochondrial DNA variation in hostspecific toxin-producing pathogens in the genus Alternaria. Ann. Phytopathol. Soc. Jpn. 63:463-469.

Kuspa, A., and Loomis, W. F. 1992. Tagging developmental genes in Dictyostelium by restriction enzyme-mediated integration of plasmid DNA. Proc. Natl. Acad. Sci. USA 89:8803-8807.

Lee, D., Ellard, M., Wanner, L. A., Davis, K. R., and Douglas, C. J. 1995. The Arabidopsis thaliana 4-coumarate:CoA ligase (4-CL) gene: Stress and developmentally regulated expression and nucleotide sequence of its cDNA. Plant Mol. Biol. 28:871-884.

Lu, S., Lyngholm, L., Yang, G., Bronson, C., Yoder, O. C., and Turgeon, B. G. 1994. Tagged mutations at the Toxl locus of Cochliobolus heterostrophus by restriction enzyme-mediated integration. Proc. Natl. Acad. Sci. USA 91:12649-12653.

Maekawa, N., Yamamoto, M., Nishimura, S., Kohmoto, K., Kuwata, M. and Watanabe, Y. 1984. Studies on host-specific AF-toxins produced by Alternaria alternata strawberry pathotype causing Alternaria black spot of strawberry. I. Production of host-specific toxins and their biological activity. Ann. Phytopathol. Soc. Jpn. 50:600-609.

Nakashima, T., Ueno, T., Fukami, H., Taga, T., Masuda, H., Osaki, K. Otani, H., Kohmoto, K., and Nishimura, S. 1985. Isolation and structures of AK-toxin I and II, host-specific phytotoxic metabolites produced by Alternaria alternata Japanese pear pathotype. Agric. Biol. Chem. 49:807-815.

Nakatsuka, S., Feng, B.-N., Goto, T., Tsuge, T., and Nishimura, S. 1990. Biosynthetic origin of (8R,9S)-9,10-epoxy-8-hydroxy-9-methyl-deca(2E,4Z,6E)-trienoic acid, a precursor of AK-toxins produced by $\mathrm{Al}$ ternaria alternata Japanese pear pathotype. Phytochemistry 29:15291531

Nakatsuka, S., Ueda, K., Goto, T., Yamamoto, M., Nishimura, S., and Kohmoto, K. 1986. Structure of AF-toxin II, one of the host-specific toxins produced by Alternaria alternata strawberry pathotype. Tetrahedron Lett. 27:2753-2756.

Nikolskaya, A. N., Panaccione, D. G., and Walton, J. D. 1995. Identification of peptide synthetase-encoding genes from filamentous fungi producing host-selective phytotoxins or analogs. Gene 165:207-211.

Nishimura, S. 1980. Host-specific toxins from Alternaria alternata: Problems and prospects. Proc. Japan Acad. (Ser. B) 56:362-366.

Nishimura, S., and Kohmoto, K. 1983. Host-specific toxins and chemical structures from Alternaria species. Annu. Rev. Phytopathol. 21:87-116.

Nishimura, S., Sugihara, M., Kohmoto, K., and Otani, H. 1978. Two different phases in pathogenicity of the Alternaria pathogen causing black spot disease of Japanese pear. J. Fac. Agric. Tottori Univ. 13:1-10.

Otani, H., Kohmoto, K., Nishimura, S., Nakashima, T., Ueno, T., and Fukami, H. 1985. Biological activities of AK-toxins I and II, hostspecific toxins from Alternaria alternata Japanese pear pathotype. Ann. Phytopathol. Soc. Jpn. 51:285-293.

Panaccione, D. G., Scott-Craig, J. S., Pocard, J. -A., and Walton J. D.
1992. A cyclic peptide synthetase gene required for pathogenicity of the fungus Cochliobolus carbonum on maize. Proc. Natl. Acad. Sci. USA 89:6590-6594.

Pavela-Vrancic, M., Pfeifer, E., van Liempt, H., Schäfer, H. J., von Döhren, H., and Kleinkauf, H. 1994. ATP binding in peptide synthetases: Determination of contact sites of the adenine moiety by photoaffinity labeling of tyrocidine synthetase 1 with 2 -azidoadenosine triphosphate. Biochemistry 33:6276-6283.

Pegg, K. G. 1966. Studies of a strain of Alternaria citri Pierce, the causal agent of brown spot of emperor mandarin (Citrus reticulata). Queensland J. Agric. Anim. Sci. 23:15-28.

Pitkin, J. W., Panaccione, D. G., and Walton, J. D. 1996. A putative cyclic peptide efflux pump encoded by the TOXA gene of the plantpathogenic fungus Cochliobolus carbonum. Microbiology 142:15571565 .

Sambrook, J., Fritsch, E. F., and Maniatis, T. A. 1989. Molecular Cloning: A Laboratory Manual. 2nd ed. Cold Spring Harbor Laboratory, Cold Spring Harbor, NY.

Scheffer, R. P., and Livingston, R. S. 1984. Host-selective toxins and their role in plant diseases. Science 223:17-21.

Schiestl, R. H., and Petes, T. D. 1991. Integration of DNA fragments by illegitimate recombination in Saccharomyces cerevisiae. Proc. Natl Acad. Sci. USA 88:7585-7589.

Shi, Z., Christian, D., and Leung, H. 1995. Enhanced transformation in Magnaporthe grisea by restriction enzyme mediated integration of plasmid DNA. Phytopathology 85:329-333.

Shiotani, H., and Tsuge, T. 1995. Efficient gene targeting in the filamentous fungus Alternaria alternata. Mol. Gen. Genet. 248:142-150.

Sweigard, J. A., Carroll, A. M., Farrall, L., Chumley, F. G., and Valent, B. 1998. Magnaporthe grisea pathogenicity genes obtained through insertional mutagenesis. Mol. Plant-Microbe Interact. 11:404-412.

Tanaka, S. 1933. Studies on black spot disease of Japanese pear (Pyrus serotina Rehd.). Mem. Coll. Agric. Kyoto Imp. Univ. 28:1-31.

Thompson, J. D., Higgins, D. G., and Gibson, T. J. 1994. CLUSTAL W: Improving the sensitivity of progressive multiple sequence alignment through sequence weighting, positions-specific gap penalties and weight matrix choice. Nucleic Acids Res. 22:4673-4680.

Timberlake, W. E. 1986. Isolation of stage- and cell-specific genes from fungi. Pages 343-357 in: Biology and Molecular Biology of PlantPathogen Interactions. NATO ASI Ser., Vol. H1. J. A. Bailey, ed. Springer-Verlag, Berlin.

Tsuge, T., Nishimura, S., and Kobayashi, H. 1990. Efficient integrative transformation of the phytopathogenic fungus Alternaria alternata mediated by the repetitive rDNA sequences. Gene 90:207-214.

Tzeng, T.-W., Lyngholm, L. K., Ford, C. F., and Bronson, C. R. 1992. A restriction fragment length polymorphism map and electrophoretic karyotype of the fungal maize pathogen Cochliobolus heterostrophus. Genetics 130:81-96

Walton, J. D. 1996. Host-selective toxins: Agents of compatibility. Plant Cell 8:1723-1733.

Walton, J. D., Ahn, J.-H., Pitkin, J. W., Cheng, Y., Nikolskaya, A. N., Ransom, R., and Wegener, S. 1998. Enzymology, molecular genetics, and regulation of biosynthesis of the host-selective toxin HC-toxin. Pages 25-34 in: Molecular Genetics of Host-Specific Toxins in Plant Disease. K. Kohmoto, and O. C. Yoder, eds. Kluwer Academic Pub., Dordrecht, The Netherlands.

Yang, G., Rose, M. S., Turgeon, B. G., and Yoder, O. C. 1996. A polyketide synthase is required for fungal virulence and production of the polyketide T-toxin. Plant Cell 8:2139-2150.

Ye, L., Buck, L. M., Schaeffer, H. J., and Leach, F. R. 1997. Cloning and sequencing of a cDNA for firefly luciferase from Photuris pennsylvanica. Biochem. Biophys. Acta 1339:39-52.

Yoder, O. C. 1980. Toxins in pathogenesis. Annu. Rev. Phytopathol. 18: 103-129.

Yoder, O. C. 1998. A mechanistic view of the fungal/plant interaction based on host-specific toxin studies. Pages 3-15 in: Molecular Genetics of Host-Specific Toxins in Plant Disease. K. Kohmoto, and O. C. Yoder, eds. Kluwer Academic Pub., Dordrecht, The Netherlands.

Yun, S.-H., Turgeon, B. G., and Yoder, O. C. 1998. REMI-induced mutants of Mycosphaerella zeae-maydis lacking the polyketide PM-toxin are deficient in pathogenesis to corn. Physiol. Mol. Plant Pathol. 52:53-66. 